\title{
Influence of Christianity on English
}

\author{
Li-Li ZHANG \\ School of Foreign Languages, Jilin Agricultural University, Changchun City, Jilin Province, 130012, \\ P.R.China,
}

Shirley19828182@sina.com

Keywords: English, Christianity, influence.

\begin{abstract}
Language is a communication tool that can be used to express thoughts and emotions. At the same time, it is also a symbol system carrying various information. Therefore, formation and development of language has marks of different aspects of social life, reflecting a distinctive culture of a certain society. As an influential religion in the western world, Christianity enriches English language. This paper illustrates the influence of Christianity on English from formation, specification and development. For Chinese English learners, it is inevitable to encounter Christianity while learning English. Therefore it also proposes some pieces of advice on English teaching and English learning.
\end{abstract}

\section{Introduction}

In ancient times, people worshiped ancestors, animals, nature as well as language. Religion formed and developed through language worshiping and utilizing. Symbolic characteristics of language have played significant role in transmission and evolvement of religion. No language, no religion. Meanwhile, religion helps to create and spread the language. Whenever there was religious reform, there would be great changes in language. Almost all religions all over the world would create a new language or use a dialect while writing their scriptures. With the spread of religion, that language was also spread. Judaism spread Aramaic, Hebrew, Aniohevotakh as well as Sephardi to different places all over the world from Palestine; Mohammedanism created by Mohammed spread Arabic with Koran to Europe, Asia as well as Africa from Southern part of Arabian Peninsula; Indian Buddhism spread Gautama as well as Sanskrit to China, Japan and so on. In addition, religion set a lot of rules for using language. As a main language of Christianity, English is deeply influenced by Christianity. With no doubt, it is beneficial to intercultural communication to analyze the influence of Christianity on English.

\section{Influence of Christianity on Old English}

Christianity was set up based on Greek and Latin which were regarded as a tool of transmitting its creed [1]. For this reason, these two old languages can survive from Germanic conquering. Since Roman Missionary Saint Augustine and his disciples spread Christianity to the British Isles in 597AD, Christianity and Latin culture have begun to infiltrate into English. With the popularization and deepening of Christianity, English has become more and more religious. Jespersen, a famous Danish linguist once said in Growth and Structure of English Language, religion has played a very important role in English development [2]. During more than 500 years from Christianity appearing in Britain to the end of Old English, churches blossomed in various places of Britain. Church schools emerged at this historic moment. As the language for sermon, Latin language and Latin culture infiltrated into English. These Latin words are related to religious equipments, rituals and so on. These words can be divided into two groups: (1) words whose religious meaning has not changed: temple, church, prayer, preach, sermon, nun, salvation, divine, etc.; (2) words whose religious meaning has changed: dogma, minister, mission, hood, sponsor, lecture, patron, etc. 


\section{Influence of Christianity on Modern English}

Modern English appeared in 16 century and at that time, Renaissance was sweeping continental Europe. Humanists in various countries fought against religious Theology with humanism of ancient Greece and Rome. Under the impact of this movement, British national consciousness was aroused. British humanist writers began to write with English instead of Latin. Old English had no norm at that time. These British humanists played an important role in specifying and unifying Old English and transforming Old English into Modern English. In addition, in 1611, Authorized Version came into being, which had an epoch-making meaning in English development history [3]. Including Old Testament and New Testament, Authorized Version was compiled with beautiful and simple prose. Its publication not only specified English, but also made English widely used in society. The success of Authorized Version laid the foundation for Modern English. Besides, another religious book named The Book of Common Prayer and Application of the Sacraments should be mentioned as well. These two books were widely read by all walks of life, no matter whether educated or uneducated. While giving remarks on these two books, Swift said that they became the standard of English, especially for common people [4].

The appearance of Authorized Version enlarged the influence of Christianity in English-speaking countries. In the book named The English Language, Ernest Weekley once remarked that apart from the books of Shakespeare, no other books have had such big influence as Authorized Version on English vocabulary [5]. It greatly contributed to enriching and perfecting Modern English.

\section{Influence on Idioms}

In the first place, Authorized Version added a lot of idioms. In English-speaking countries, people believe in God. For them, God is everywhere, all-powerful and omniscient. It is God who created all creatures and govern everything. There are a lot of idioms related to God, including God shapes the back for the burden; when God will, all winds bring rain; God doth what he will. There are also a great number of idioms related to clergies, such as Why ask the Bishop when the Pope's around; the King and the Pope, the lion and the wolf. According to the Bible, people originally are evil. However, through their own efforts, they can eradicate their original sin. Therefore, people believe that as long as they make efforts to do everything, they will succeed. As a result, a lot of idioms encouraging people to do things better can be found in English. For instance: What is worth doing at all is worth doing well; whatever you do, do with your might; things done by halves are never done right. In addition, under the influence of Christianity, people always seek change. There is nothing permanent except change; variety is the spice of life; discontent is the first step in progress; life is a battle from cradle to grave; life, to be worthy of a rational being, must be always in progression. Influenced by Christianity, people in western world emphasize the future and because of this, people value the efficiency and most of them are optimistic. Thus there are the following idioms in English. Quick at meal, quick at work; quick feet and busy hands fill the mouth; God never shuts one door but open another; if you don't succeed, try, try and try again. Other idioms include an eye for an eye; the apple of one's eye; the salt of the earth, to wash one's hands off; to cast pearls before swine; to kick against the pricks; new wine into old bottle [6].

\section{Influence on Allusions}

In the second place, Authorized Version added many allusions [7]. These allusions have become household words. They embody their national religious consciousness. For instance, the loaves and fishes came from Matthew [8]. In the book, it is said that Jesus fed many people with loaves and fishes and then many people followed him. While some of them did not intend to listen to his lesson, but for the food. As a result, the phrase the loaves and fishes means "personal gain or self interest". The second example is broken reed. This allusion is from Isaiah [8]. It is said that "Lo, thou trustiest in the staff of this broken reed, on Egypt; whereon if a man lean, it will go into his hand, and pierce it; so is Pharaoh king of Egypt to all that trust in him". Now, broken reed means unreliable persons or things. To turn the other cheek was written in Matthew. Jesus said to his disciples: "But whoever shall smite thee on my 
right cheek, turn to him the other also". What Jesus meant is that when others humiliate you, you should ensure. Now it means "to tolerate". A camel to go through a needle's eye is also recorded in Matthew. Jesus told a person who asked for wisdom that if they wanted to be a perfect man, please sell out all your properties and gave all your money to the poor. In addition, you should follow me. After hearing that, the person sadly left because he had numerous properties. Then Jesus told his disciples that it is easier for a camel to go through a needle's eye than for a rich man to enter the kingdom of God. These allusions use simple words to reveal profound moral. A doubting Thomas refers a skeptical person who refuses to believe something until he or she has actually seen the entire proof or evidence for it. This expression derives from Thomas, one of the twelve disciples who at first did not believe in Jesus resurrection. Then Jesus satisfied his doubts. Finally Thomas confessed Jesus to be his Lord and God. A Solomon now refers to a wise person. Originally Solomon was the King of the Hebrews around the $10^{\text {th }}$ century B. C. and was known for his wisdom. A Kiss of death derives from Judas Iscariot's of Jesus in his betrayal. Now it means an act of affection or good will on the surface which proceeds or is itself an act of malice.

\section{Influence on Maxims}

In the third place, Authorized Version added many maxims [9]. Because of the authority position of Bible in Christianity, maxims in the Bible have particular power. They are often found in written English and spoken English, forming a kind of national moral values and influencing the norms of people's actions. For instance, hatred stirreth up strifes, but love covereth all sins; there shall no evil happen to the just, but the wicked shall be filled with mischief; love your neighbor as yourself; resentment kills a fool and envy slays the simple; I will speak out in the anguish of my spirit. I will complain in the bitterness of my soul; is not wisdom found among the aged? Does not long life bring understanding? The lamp of the wicked is snuffed out; the flame of his fire stops burning; Man does not comprehend its worth.

\section{Influence on Oral English}

Many religious words recorded in Authorized Version now have been used in daily life. People in English-speaking countries believe that the world is created by God. Therefore, they like the word "God" very much. They often say "God" and "Oh, my God" when they express their surprise. When they want to succeed, they often say "May God bless me!" When they realize that they have made a mistake, they often say "God save the mark!" When they pray for something, they often say "Please God!". When they curse somebody or something, they often say "God damn you!".

\section{Influence on Literature}

Nothing but the Bible has had so great an influence on American and British Literature. With the transmission of Christianity, Bible became a well-known book. Writers of different generations in America and Europe have gained various materials from the Bible. Many expressions and phrases in the Bible have been cited. For example: The East of Eden written by American writer John Steinbeck [10]; Paradise Lost, Paradise Regained and Samson Agonistes written by famous British writer John Milton [11]; Absalom, Absalom written by American writer William Faulkner [12]. Shakespeare, the great British writer was one of the writers whose idea was influenced by Christianity. In his life, he wrote 37 dramas in total and almost in every drama, there is the influence of the Bible. For instance, in his famous

work Hamlet; he cited the allusion of God Creating the World and Cain' Killing Brother. The idea shown here is that people are originally evil [13].

\section{Summary}

Language is closely connected with culture and is greatly influenced by culture as well. Religion is an important part of human ideas and culture, so language is closely connected with religion. The reason why Christian thinking, belief and symbol can leave marks on English is that Christianity influences lives of people in numerous aspects. With Christianity as the dominant religion in English speaking countries, 
Christian culture has a great influence on the English language. It is the influence of Christianity on English that makes English change all the time, including the changes in idioms, allusions, maxims and American and British literature and so on. Moreover, Christianity still influences English now. Deng Yanchang [14] once pointed that language reflected the characteristics of a nation. It covered not only the history and cultural background, but also the values, life and thinking style. Chinese learners of English are deeply influenced by Buddhism and therefore they will ignore the religious differences between Buddhism and Christianity. As a result, there will be inter-cultural communication failure. In order to avoid inter-cultural communication failure, English teaching should cover culture. Chinese learners of English should learn the national tradition, psychological states, philosophy and religion of China and English-speaking countries. They should master the similarities and differences.

\section{Acknowledgement}

This research was financially supported by Social Science Foundation of Jilin Province, China (Grant NO. 2012005) and the Fundamental Research Funds for Jilin Agricultural University, Jilin Province, China (Grant NO. 2013xjyb005).

\section{References}

[1] Y. Zhou, Early Christianity, Shanghai People's Publishing House, Shanghai, 2005.

[2] O. Jespersen, Growth and Structure of English Language $\left(10^{\text {th }}\right.$ edition $)$, Blackwell Publishers, London, 1982.

[3] J. Hastings, The Dictionary of the Bible, Charles Scribner's Sons, New York, 1909.

[4] F. Mosse, Brief History of English, translated by Shui Tiantong, Foreign Language Teaching and Research Press, Beijing, 1990.

[5] E. Weekley, The English Language, Ander Deutsch, Germany, 1952.

[6] Q. Li. English Idioms and Christianity, Journal of Tianjin Foreign Language College, vol. 2, pp. 42-46, 2002.

[7] C. H. Zeng, Story of Bible, Chinese Social Science Research Institute Press, Beijing, 1994.

[8] J. L. Xie and G. Q. Lu, Bible Allusions, Fudan University Press, Shanghai, 1998.

[9] Information on http://www.360doc.com.

[10] J. Timmerman, Introduction to John Steinbeck, The Long Valley, Penguin Publishing, London, 1995.

[11] J. Milton, Paradise Lost, The Verse, Penguin Publishing, London, 1668.

[12] J. Blotner, Faulkner: A Biography, Random House, New York, 1984.

[13] W. Shakespeare, Hamlet, Fujian Education Press, Fujian, 2009.

[14] Y. C. Deng and Y. Q. Liu, Language and Culture, Foreign Language Teaching and Research Press, Beijing, 1989. 